\title{
Corporate Governance and Performance: Evidence from Italian Companies
}

\author{
Fabrizio Fratini' ${ }^{1}$, Patrizia Tettamanzi ${ }^{1,2}$ \\ ${ }^{1}$ Cattaneo University (LIUC), Castellanza, Italy \\ ${ }^{2}$ Bocconi University, Milan, Italy \\ Email: ffratini@liuc.it, patrizia.tettamanzi@unibocconi.it
}

Received 11 March 2015; accepted 20 April 2015; published 21 April 2015

Copyright (C) 2015 by authors and Scientific Research Publishing Inc.

This work is licensed under the Creative Commons Attribution International License (CC BY). http://creativecommons.org/licenses/by/4.0/

(c) (i) Open Access

\section{Abstract}

The purpose of this paper is to verify the presence and intensity (extent) of the relationship between corporate governance and performance in Italian listed companies by using both accounting and non-accounting performance measures. We extended previous literature in considering all the main aspects of governance (board structure and ownership structure) and all relevant peculiarities of Italian entrepreneurial system (family business, concentrated ownership, State ownership, pyramidal groups). In the first part of the paper, we used regression analysis on a sample of 182 Italian listed companies to find that firm performance was positively related to board size and audit committee's effort and negatively related to leverage, although with a very low coefficient. No particular relationship was highlighted for ownership structure. We tested the consistency of this finding by doing a follow-up analysis between a sub-group of 134 of 2003 sample companies and the same companies in $\mathbf{2 0 0 7}$ to verify the stability of the determinants of performance and their relative impact overtime. What we found was that only board size kept its positive relation with performance. Audit committee and leverage lost their relevance in 2007 sample in which the presence of a compensation committee showed a positive impact on performance. From our findings, we can conclude that, according to other studies (Belcredi \& Rigamonti [1]), the relationship among ownership and corporate governance structure and firm performance is ambiguous. The ambiguity improves if considering the relationship overtime.

\section{Keywords}

Board Composition, Ownership Structure, Performance, Insiders, Italy

\section{Introduction}

The main objective of this study is to verify the existence and the strength of the relationship between corporate 
governance structures of Italian listed companies and their performance.

In particular we aim at identifying the combined contribution of two main components of governance (board composition and ownership structure) to company performance.

This paper extends upon previous literature on Italian listed companies in many respects concerning both board composition and ownership structure:

- with reference to board composition, first of all it does not consider only the effect of the board of directors (or audit committee), but includes also the possible influence of two of the most widespread internal committees in actual corporate structure: nominating committees and compensation committees; secondly it also includes another very important committee in the Italian context, "collegio sindacale";

- with reference to ownership structure, the study considers the effect of substantiating all known peculiarities of the Italian corporate system: concentrated ownership, family ownership, state ownership and pyramidal groups.

In verifying the strength but also the robustness of the possible relationship between corporate governance and corporate performance, we considered a market performance measure (Tobin Q).

The content of this paper can be summarised as follows:

- a review of relevant literature and the formulation of hypotheses;

- a description of data sources and of variables used;

- a description of the model and its main results;

- some concluding remarks.

\section{Literature Review and Formulation of Hypotheses}

\subsection{Literature Review}

In recent years an intense debate has been developing internationally on themes relating to corporate governance.

In particular this happened in the aftermath of huge financial scandals in which some apparently robust US corporations were involved.

The economic and social impact of those crises has brought about the need to investigate the causes, with the aim of preventing similar incidents from happening again (Abdel-Khalik [2]; Revsine [3]; Blair [4]; Palepu \& Healy [5]).

In particular, public opinion started to ask if those corporations were really managed in the best interests of their shareholders/stakeholders and if the concentration of powers in the hands of management had been equilibrated by a monitoring system which could have prevented excessive risk-taking habits or opportunism.

The theme, although current, is not particularly new in the field of economic studies; one of the first structured works about the issue dates back to the early 30s (Berle \& Means [6]).

The underlying concept is the conflicting relationship between managers and shareholders/owners and the possible solutions by which this relationship can be managed in the best interests of the latter.

In the study of this phenomenon, a great majority of papers follow an economic and corporate finance approach and this is also what we are going to do. In a financial perspective corporate governance "[...] deals with the way in which suppliers of finance to corporations assure themselves of getting a return on their investment" (Shleifer \& Vishny [7]).

The dominant issue is the effectiveness of corporate governance mechanisms to guarantee the satisfaction of the needs of suppliers of finance with a major emphasis on those of shareholders whose main interest is that of maximising the value of resources they have invested in the enterprises. This way of approaching corporate governance has benefited, over the years, contributions coming from different disciplines among which an important role must be attributed to economic theory and, in particular, to property rights and agency theories.

The main issue in the agency relationship, applied to the phenomenon of public companies, derives from the degree of separation between ownership and control (Jensen \& Meckling [8]) or, in other words, from the potential conflict of interest between shareholders (principals) and managers (agents).

In the agency theory perspective, which is based on economic rationality of individuals, the managers, who have been assigned relevant powers and resources, will tend to follow their own interests instead that of the principals. This can happen because of the incompleteness of the contract which regulates their respective obligations and the strong information asymmetry which favours the agent. 
It is clearly stated in the literature that opportunistic behaviour of management may impact negatively on shareholders both in terms of lower market value shares and lower dividends. The ways in which management can pursue its own interests have been highlighted both by the original work of Jensen \& Meckling and by subsequent contributions (Fama \& Jenses [9]; Shleifer \& Vishny [7]): company dimensional increases, even beyond the levels that can be considered economically efficient; financing of negative net present-value projects, perquisites consumption, etc., are all good examples of possible distorted management behaviour.

If there were no way to align agents' interest with that of the principals, the principal would be forced to pay the price of opportunism by getting a lower value.

Otherwise it is rational to suppose that since the principal has an advantage, in terms of cost-benefit considerations, he will set up a monitoring and control system, trying to reduce the misalignment and its negative effects.

It is the same theory that, after having elicited possible risks, proposes to use instruments which are believed to be useful in correcting behavioural management distortions and in protecting shareholders' interests.

The main objective of these proposals is to modify management incentives in operating opportunistically. Among possible corrective measures indicated in the literature (Fama \& Jensen [9]; Keasey, Thomson, \& Wright [10]) it is possible to find:

- management incentive programmes created to align the agent's interest to that of the principal, such as stock options or managerial ownership;

- improve the internal control systems to monitor more accurately the activities of management, especially when main business decisions are taken;

- the reaction of the capital and the executive job markets: the capital market whose efficiency in signalling the value of investments can contribute to stimulating the management's effort; the direct consequence of an efficient capital market is an active market of corporate control through which badly managed companies can be acquired by investors, turned around and made profitable. The executive job market whose function is to "rank" managers in accordance with their abilities and managerial performance: if a company is underperforming, it is possible that management rankings could be reduced, which is unfavourable; this mechanism creates a strong incentive for managers to avoid opportunistic behaviour that could reduce the value and the development perspectives of the corporations they direct.

Building on these and other pieces of theory, many studies have been devoted to verifying the impact of a single set of instruments that could solve the misalignment of interests between principal and agent. Studies have been conducted considering all aspects of the board of directors with regard to the ways in which different kinds of ownership can influence results and value.

In the following paragraphs we identify which factors were predominantly considered and which results were obtained, thus formulating the hypotheses to be tested in the empirical analysis.

\subsection{Explaination and Formulation of Hypotheses}

\subsubsection{Board Composition and Company Performance}

The studies concerning the impact of the board composition have been developed over a period of time. Initially the effort was concentrated only on an analysis of the board of directors (particularly considering the differential effects of executive and non-executive directors); the field of interest then widened to include almost all relevant internal committees (audit committee, nominating committee, compensation committee, etc.).

In the following pages we identified those aspects of the committees that have been prevalently studied and that, in our opinion, are the most interesting:

- the number and independence of directors - In an agency theory perspective directors are assigned the role of guaranteeing that managers are acting in the best interests of shareholders. Directors on a board have different powers of authority and varying involvement in corporate operations. Differentiating first of all among executive directors (i.e. the CEO who is heavily involved in managerial activities), non-executive directors (NED), i.e. those directors who have not received a particular management assignment, and independent non-executive directors (INED). The latter are those who, beyond being non-executives, do not have family or business interests in the corporation, its managers and other directors. In general terms, the role of NEDs should be monitoring both managers (Fama [11]; Fama \& Jensen [9]) and supporting the company with their skills. In the literature, great emphasis has been given to the role of NEDs on the assumption that a 
greater proportion of them on the board could correspond to more effective control of management, an increased alignment of interests between managers and stockholders and positive consequences on performance and corporate value. Alternative theories exist when conclusions are exactly the opposite. In stewardship theory, for instance, the assumption is that managers have a spontaneous tendency to act in the best interests of shareholders in every situation. If this is true, only a greater proportion of executive directors on the board could allow the company to benefit from the skills developed by following direct corporate operations. If agency theory hypothesises a positive relationship between NEDs and performance, the results of empirical studies are not conclusive. In particular they have shown:

- $\quad$ no significant relationship (Hermalin \& Weisbach [12]; Baghat \& Black [13]; Dulewicz \& Herbert [14]);

- $\quad$ a negative relationship (Pfeffer [15]; Yermack [16]; Muth \& Donaldson [17]; Agrawal \& Knoeber [18]);

- a positive relationship (Dehaene, De Vuyst, \& Ooghe [19]; Kiel \& Nicholson [20]).

Considering this in the present study, we have chosen to adhere to the theory with reference to the issue of independence by stating:

- HYPOTHESIS No. 1-A greater proportion of NEDs corresponds to better company performance.

- HYPOTHESIS No. 2-A greater proportion of INEDs corresponds to better company performance.

Other factors have been considered concerning the board of directors and its influence on performance; one of which is board dimension.

Agency theory suggests that a higher number of directors could enhance control on management thus contributing to a better performance. The same conclusions are reached, though through different paths, from a resource based theory perspective which links a higher number of directors to a stronger ability for corporations to benefit from their specialised skills by creating a long term relationship with strategic environment. Notwithstanding the convergence of the diagnoses, even in this case empirical findings are mixed: Dalton, Daily, Johnson, \& Ellstrand [21] and Kiel \& Nicholson [20] found a positive link while Yermack [16] and Eisenberg, Sundgren, \& Wells [22] a negative one. On this issue some authors warn about coordination problems that could be caused by oversized boards (Lipton \& Lorsch [23]; Jensen [24]) stating that over a certain number of members the effectiveness of boards could be at least partially compromised.

For the present analysis, the following hypothesis has been considered:

- HYPOTHESIS No. 3-Board dimension is positively related to company performance.

- Chairman/CEO duality - In the relevant literature the presence of insiders, that is board members who are directly involved in management operations (executive directors) is considered a fact that could hamper the monitoring activity of management by the board. This can be particularly true if, as often happens, a single person shares the responsibilities of both Chairman and Chief Executive Officer (CEO). This eventuality, referred to in the literature as Chairman/CEO duality, increases the risk that board control of managers is somehow limited and/or distorted. Notwithstanding the apparent rationality of these considerations there does not seem to be any definite empirical support. Many studies find no significant relationship between these dual roles and performance, with others even showing a positive one (Boyd [25]; Dalton, Daily, Ellstrand, \& Johnson [26]; Muth \& Donaldson [17]; Vafeas \& Theodorou [27]).

For theory clarification we prefer to hypothesise as follows:

- HYPOTHESIS No. 4-Chairman/CEO duality is negatively related to company performance.

- Directors' effort-If board structure is supposed to have an influence on company performance it is equally logical to suppose that performance can be influenced by the quantity and quality of effort directors devote to their duties. In previous studies directors' qualities were often measured using the number of appointments they got on the boards of other corporate entities (interlocks). Also in this case the empirical findings show a positive link with performance (Dowen [28]) and no link (Klein [29]).

In this paper we hypothesise a positive relationship summarised in the following statements:

- HYPOTHESIS No. 5a-The presence of interlocks is positively related to company performance.

- HYPOTHESIS No. 5b-The number of interlocks is positively related to company performance.

If directors' effort can be "proxied” by interlocks it does not seem so illogical to suppose that the number of yearly board meetings can also be a good measure.

Considering the point given above, a higher number of meetings can be associated to stronger effort and, possibly, better monitoring activity, but there is still no clear evidence of this in the literature.

For this reason we prefer to propose a neutral effect of this factor:

- HYPOTHESIS No. 6-The annual number of board meetings is related to company performance. 
- Audit committee (and other internal committees) - The presence of a board sub-committee which is responsible for monitoring the internal control system, internal auditors' activity and to choose and follow financial auditors' activity is strongly supported by best governance practices worldwide. Unfortunately, also for audit committees, the empirical findings of their influence on performance are mixed (Wild [30]; Klein [29]; Vafeas \& Theodorou [27]).

Audit committees, if formed by independent individuals in particular, could have the merits necessary to enhance the reliability of an internal control system. This fact could exert a positive effect on market perceptions about the corporation giving a signal of its abilities to run its operations in a transparent, correct and effective way. The market should therefore appreciate this attitude and assign higher value to those companies who proceed in that direction. For this reason in the present study we have assigned a positive impact to audit committee by stating:

- HYPOTHESIS No. 7a-The presence of an audit committee is positively related to company performance.

- HYPOTHESIS No. 7b-The degree of independence of the members of audit committee is positively related to company performance.

The analysis on audit committees was extended by considering not only structural factors but also functional ones (annual meetings):

- HYPOTHESIS No. 7c-The annual number of audit committee meetings is related to company performance.

With reference to the other internal committees (nominating and compensation committees) we preferred to be coherent with the assumption made for audit committees, considering factors like presence of the committee and its independence. According to agency theory, the presence of similar internal committees allows control over management behaviour when delegating responsibilities and monetary issues. It appears meaningful although not extensively supported by the previous literature (Brown \& Caylor [31]) to think that a good control system on such delicate issues can try to prevent the temptation to act opportunistically. As for audit committees, also in this case we stated:

- HYPOTHESIS No. 8a-The presence of a nominating/compensation committee is positively related to company performance.

- HYPOTHESIS No. 8b-The degree of independence of the members of nominating/compensation committee is positively related to company performance.

Considering the fact that the analysis is based on Italian companies, "collegio sindacale” (board of auditors) could not be omitted.

This committee in Italy falls under the jurisdiction of the law and is compulsory for all listed companies, following its rules and regulations.

Instead of considering the above (presence and independence), we chose to observe two other aspects: the average number of appointments of the members and the number of meetings held during the year. From a theoretical point of view the lower the average number of appointments the greater the portion of time devoted to a single company. In this case, as with the board of directors, the limitations in using this kind of measure do not consider a multitude of other professional activities the member could do apart from sitting on other listed companies' boards.

Considering the annual number of meetings, we hypothesised that the higher the number the better the control activity being put forward as follows:

- HYPOTHESIS No. 9a-The average number of other board of auditors' members' appointments is negatively related to company performance.

- HYPOTHESIS No. 9b-The annual number of board of auditors' meetings is positively related to company performance.

\subsubsection{Ownership Structure and Company Performance}

At an empirical level, ownership structure was initially analysed under two main points of view: the percentage of shares owned by the managers and the concentration of ownership.

Referring to the first point, the majority of researches show a non linear relationship with performance (Morck, Shleifer, \& Vishny [32]; McConnell \& Servaes [33]; Hermalin \& Weisbach [12], Holderness, Kroszner, \& Sheehan [34]; Short \& Keasey [35]). According to these studies, performance tends to increase when the level of management, starting from a particularly low level, tends to increase; but this positive link tends to become 
negative when a certain level of management ownership is reached; this made many researchers think about a trade-off involving managers who are divided between getting advantages from their proper role or by becoming owners themselves of a part of the company they manage.

In this study we will not deny that a relationship can exist, but our formulation tends to be more cautious considering the high proportion of ownership concentration in the Italian context. Consequently the hypothesis is:

- HYPOTHESIS No. 10-The level of managerial ownership is related to company performance.

As stated earlier, the Italian governance system witnesses a high level of ownership concentration. From an agency theory perspective, a greater share of the company should correspond to a greater interest in closely following operations. The majority shareholder is indeed the person who has the most to lose when there is mismanagement or other similar problems present within the company. Many studies have analysed the impact of shareholder type on corporate performance, finding a positive relationship when considering relevant shareholders (Lins [36]; La Porta, Lopez-de-Sinales, Shleifer, \& Vishny [37]), even if other researches found no effect of ownership on corporate performance (Demsetz \& Villalonga [38]).

Other authors have tested the influence of minority shareholders in particular as monitors of corporate operations. In this case the majority of them found no significant relationship (McConnell \& Servaes [33]; Agrawal and Knoeber [18]; Volpin [39]).

With reference to relevant shareholders the hypotheses are as follows:

- HYPOTHESIS No. 11a — The share of capital held by relevant shareholders is positively related to company performance.

- HYPOTHESIS No. 11b-The presence of a relevant shareholder whose participation goes beyond certain thresholds is positively related to company performance.

Rethinking critically the emphasis that the first studies on ownership concentration posed on the role of relevant shareholders, some commentators argue that other aspects have probably been underestimated. Among these, it is suggested that the nature of the relevant shareholder can have a significant differential impact on performance (Denis \& McConnel [40]). The point is that different kinds of owners (i.e. a family, another enterprise or the State) correspond to different ways of monitoring corporate operations with different potential impacts on corporate performance.

Another element to consider is the different kind of shareholders, concerning the peculiarities of the Italian system compared to the public company model. Family control, pyramidal structures and, though reduced in the last years, State ownership are all strongly present in Italy (Bianco \& Casavola [41]; Bianchi, Bianco, \& Enriques [42]).

It is also a matter of fact that this situation is very common in many other countries (La Porta, Lopez-de-Sinales, \& Shleifer [43]; Faccio \& Lang [44]). It is therefore not surprising that much effort has been devoted by researchers to studying the effects of these alternative ownership structures on performance. Considering the US reality, the evidence is mixed: some papers refer to a negative relationship (Holderness \& Sheehan [45]), while some more recent ones highlight a positive correlation (Anderson \& Reeb [46]; Villalonga \& Amit [47]).

Also the studies referring to other countries report non corresponding results: a negative relationship (BenHamar \& André [48] [49]) or no significant relationship (Gorriz \& Fumas, 2005) in some cases, while other contributions highlight a positive impact of family control on corporate performance (Barontini \& Caprio [50]). The last study in particular has considered companies from eleven (11) different continental European countries. The hypothesis is as follows:

- HYPOTHESIS No. 12-Family ownership is positively related to company performance.

As for family ownership, we tried to consider the effect of another well known Italian phenomenon, that, though reduced in its relevance, is still present in some strategic sectors of the Italian economy: State ownership.

To treat the issue properly, much more significance should have been devoted to a literature review concerning public intervention and its effects, but this would have been beyond the scope of this paper. We have drawn the attention to some previous pieces of empirical work that have treated the theme of the relationship between State ownership of corporations and corporate performance.

Those studies which concentrated on the European situation found a negative relationship (Kocenda \& Svejnar [51]; Grünfeld, Benito, \& Goldeng [52]) even though the authors underlined that their results should be taken cautiously because private ownership does not always perform better. Outside Europe many studies are concentrated on emerging countries with an increasing emphasis on China. A very recent survey on that country shows a non linear relationship between State ownership and corporate performance: when the percentage of 
shares owned by the State is low the relationship seems to be negative, thus turning into a positive one as the stake of the State increases (Tian \& Estrin [53]).

We place much more emphasis on the results of studies concerning European countries, thus formulating the following hypothesis:

- HYPOTHESIS No. 13-State ownership is negatively related to company performance.

The last factor considered, for its importance in the Italian corporate structure, is the use of non direct (often pyramidal) control mechanisms. Previous studies of Italian cases showed how the effect of the pyramidal ownership mechanism on performance could be influenced by the use of different performance measures (Bianco \& Casavola [41]); more recently a positive effect on performance was found when cash-flow ownership coincided with share ownership (Lemmon \& Lins [54]; Volpin [39]). Building on the above, the following is hypothesised:

- HYPOTHESIS No. 14-Pyramidal control mechanisms are negatively related to company performance.

There are other factors, considered in international literature, that were not considered in the present study. One of the most relevant is the effect of take-overs. We decided to exclude it because it is not considered to be relevant in the Italian context (Melis [55]; Bianchi and others [42]).

\section{Data and Variables}

We used 3 different samples for this study. The first one (WS03) is composed by 182 non financial listed companies. From the original group of about 200 non financial listed companies, Italian subsidiaries of foreign companies were excluded. Other exclusions were based upon the impossibility of getting all required data about governance and, in some cases, on the particular financial situation of the companies (i.e. Parmalat, Cirio, Giacomelli, etc.).

Since we wanted to compare the 2003 situation with that of the same companies in 2007, we extracted from WS03 a sub-group of 134 companies (RS03) for which we made sure to get all needed data also for year 2007.

The third sample (RS07) is the same group of 134 companies for which we collected governance and performance data referring to 2007.

The data about capitalisation, ownership, internal committees, etc. were gathered from official documents of the Italian Stock Exchange and "Commissione Nazionale per le società e la Borsa" (Consob). Balance sheets data was gathered from Aida (from Bureau Van Djck Electronic Publishing) which is a database of company accounts, ratios, activities, ownership, subsidiaries and management for 550,000 live Italian companies.

We considered Q-ratio as performance measure. Q-ratio is often used in the literature as a proxy of Tobin Q (Tobin [56]) because of the difficulties of calculating the elements that are part of the original ratio: it is determined as the ratio of market value of all outstanding company shares plus book value of its long term debts divided by book value of total assets; notwithstanding its hybrid nature it is widely used as a proxy of market performance of a company; we determined an average value for this indicator. Years 2003 and 2004 were considered for the average value of 2003 and years 2007 and 2008 values were used to compute average Q-ratio for 2007. A logarithmic transformation was also used to solve some skewness problems.

The use of average values is coherent with what is suggested in the literature to reduce the periodical fluctuations of the indicators (Kiel \& Nicholson [20]).

Independent variables are the following:

- BOARD_LOG_is calculated as the natural logarithm of the number of directors within the board; it is an indicator frequently used in previous studies to represent board dimension; the use of the logarithm allowed us to solve the skewness problems in the distribution of data;

- BRDMEET-is the number of meetings held by the board of directors during the year of reference; this variable was used as a proxy of the directors' effort in attending to their duties;

- NED_PERC-is the proportion of NEDs on the total number of Directors;

- INED_PERC—is the proportion of INEDs on the total number of Directors;

- FAMILY - is a dummy variable whose value is 1 if on the board members of the same family are present and 0 otherwise; we wanted to monitor this aspect as a signal of family influence within the boards;

- DUALITY - is a dummy variable whose value is 1 if the Chairman of the board of directors is also the Chief Executive Officer and 0 otherwise;

- INTERLOCKS - measures the average number of appointments held by directors in other listed or dimensionally relevant corporations; a dummy variable (INTERLOCK_DUMMY) whose value is 1 if at least an interlock is present and 0 otherwise was also used; 
- AUDIT_DUMMY - is a dummy variable whose value is 1 if the audit committee is present and 0 otherwise;

- AUDIT_IND—is the proportion of INEDs sitting on the audit committee;

- AUDIT_MEET_-measures the number of meetings of the audit committee held during the year;

- NOMIN-DUMMY -is a dummy variable whose value is 1 if a nominating committee is present and 0 otherwise;

- NOMIN_IND—is the proportion of INEDs sitting on the nominating committee; considering the extremely low number of INEDs in the committee a dummy variable, (NOMIN_IND_DUMMY) assuming the value of 1 if at least $50 \%$ of the committee was composed of independents, and 0 otherwise, was also used;

- COMPENS_DUMMY - is a dummy variable whose value is 1 if a compensation committee is present and 0 otherwise;

- COMPENS_IND—is the proportion of INEDs on the compensation committee;

- SIND_CHAR - is the average number of other appointments the members of collegio sindacale (board of auditors) held in other listed or dimensionally relevant companies;

- SIND_MEET_-is the number of meetings of collegio sindacale (board of auditors) held during the year;

- SHAREHLDR - is the percentage of shares of the corporation owned by the biggest shareholder;

- BLOCK25-is a dummy variable whose value is 1 if the stake of the biggest shareholder is at least $25 \%$ and 0 otherwise;

- BLOCK50-is a dummy variable whose value is 1 if the stake of the biggest shareholder is at least $50 \%$ and 0 otherwise;

- BLOCK_FAM — is a dummy variable whose value is 1 if the biggest shareholder is a single individual or a family and 0 otherwise; in measuring the variable we considered all relevant pieces of information on ownership structure without considering the corporate veil used;

- BLOCK_GVT_-is a dummy variable whose value is 1 if the biggest shareholder is the State or any other public authority and 0 otherwise;

- PYRAMID - is a dummy variable whose value is 1 if the biggest shareholder is another company or if the majority of shares of the other relevant shareholders are held through an Italian or a foreign company and 0 otherwise;

- SHARE2_NUM - is the number of all relevant shareholders (those with a stake of at least $2 \%$ of capital) including the biggest shareholder;

- BOWN-is the total percentage of shares held by the managers of the company;

- AT__is a qualitative variable representing the activity sector of the company (as stated by ATECO 2002 classification); ATECO 2002 is the classification of economic activities, set by the Italian National Statistical Institute (ISTAT), to be adopted in all current statistical surveys. It is the national version of NACE (Rev. 1.1) classification defined at a European level and partially corresponding to ISIC v.3;

- ASSET_LOG_-is the natural logarithm of the amount of total assets reported in the balance sheet of the company;

- LT_DEBT_-is the amount of long term debts reported in the balance sheet of the company;

- LEV - is the leverage measured on the values reported in the balance sheet of the company.

\section{Data Analysis for 2003}

Table 1 reports descriptive statistics for whole sample 2003 (WS03). Table 2 reports the total number of $1 \mathrm{~s}$ and $0 \mathrm{~s}$ (and their frequencies) for dummy variables.

From the combined study of the two tables it is possible to highlight some interesting elements for the analysis of the sample.

The ownership structure is strongly characterised by the concentration of ownership since in $87 \%$ there is a shareholder whose participation is at least $25 \%$ of capital; this percentage decreases to $64 \%$ when considering those shareholders with a stake of at least $50 \%$. This fact, combined with the consideration that, on average, the biggest shareholder owns $49.51 \%$ of capital shows how far the Italian corporation is from that of the public company. The data is coherent with what was reported in other studies in which, on average, the biggest shareholder's stake was 48\% (Aganin \& Volpin [57]); in the same study the percentage of companies without such big shareholders was lower; this was probably due to the fact that a value of $25 \%$ (instead of $20 \%$ ) was chosen to decide if a company could be considered to have a relative majority shareholder. 
Table 1. Descriptive statistics whole sample 2003.

\begin{tabular}{|c|c|c|c|c|c|c|}
\hline & $\mathrm{N}$ & Min & Max & Average & Median & Standard Dev. \\
\hline LTDEBT_03 & 182 & 0 & 21.381433000 & 354.249357 & 15.258990 & 1.835486344 \\
\hline LTDEBT_03_LOG & 151 & 7.467371 & 23.785789 & 16.926996 & 17.110643 & 2.746734 \\
\hline ASSET_03 & 182 & 15.988.099 & 108.887.616.551 & 2.142.708.539 & 239.757 .829 & 9.976132373 \\
\hline ASSET_03_LOG & 182 & 11.603205 & 24.849593 & 19.422904 & 19.279088 & 1.704386 \\
\hline LEV_03 & 182 & -636.210000 & 1783.570000 & 248.580700 & 201.160000 & 210.949300 \\
\hline BOARD & 182 & 4.000000 & 22.000000 & 9.082418 & 9.000000 & 3.151570 \\
\hline BOARD_LOG & 182 & 1.386294 & 3.091042 & 2.150144 & 2.197225 & 0.334499 \\
\hline NED & 182 & 0.000000 & 16.000000 & 5.763736 & 5.000000 & 2.949708 \\
\hline NED_PERC & 182 & 0.000000 & 0.941176 & 0.622128 & 0.639610 & 0.194788 \\
\hline INED & 182 & 0.000000 & 13.000000 & 3.241758 & 3.000000 & 1.996354 \\
\hline INED_PERC & 182 & 0.000000 & 0.857143 & 0.359628 & 0.333333 & 0.184979 \\
\hline BRDMEET & 182 & 1.000000 & 25.000000 & 8.285714 & 8.000000 & 3.496757 \\
\hline INTERLOCKS & 182 & 0.000000 & 9.780000 & 2.021896 & 1.430000 & 2.037871 \\
\hline AUDIT_IND & 182 & 0.000000 & 100.000000 & 61.687912 & 66.600000 & 36.130815 \\
\hline AUDIT_MEET & 182 & 0.000000 & 13.000000 & 3.054945 & 3.000000 & 2.572110 \\
\hline NOMIN_IND & 182 & 0.000000 & 100.000000 & 4.947802 & 0.000000 & 20.503242 \\
\hline COMPENS_IND & 182 & 0.000000 & 100.000000 & 37.809890 & 33.300000 & 36.507329 \\
\hline SIND & 182 & 3.000000 & 8.000000 & 3.115385 & 3.000000 & 0.549117 \\
\hline SIND_CHARGES & 182 & 0.000000 & 13.660000 & 1.192352 & 0.660000 & 1.890688 \\
\hline SIND_MEET & 182 & 4.000000 & 25.000000 & 7.571429 & 6.000000 & 3.922292 \\
\hline SHAREHLDR & 182 & 7.530000 & 89.990000 & 49.507527 & 54.050000 & 19.454237 \\
\hline SHARE2_NUM & 182 & 1.000000 & 20.000000 & 4.379121 & 3.500000 & 3.189105 \\
\hline BOWN & 182 & 0.000000 & 88.060000 & 32.278180 & 29.525500 & 28.670920 \\
\hline TOBIN_AVG & 179 & 0.074754 & 4.894980 & 1.058252 & 0.895045 & 0.685593 \\
\hline LOG_TOBIN & 179 & -2.593549 & 1.588210 & -0.117508 & -0.110881 & 0.604586 \\
\hline
\end{tabular}

Table 2. Dummy variables.

\begin{tabular}{|c|c|c|c|c|c|c|c|c|c|}
\hline & \multicolumn{3}{|c|}{ COLUMN I } & \multicolumn{3}{|c|}{ COLUMN II } & \multicolumn{3}{|c|}{ COLUMN III } \\
\hline & \multicolumn{3}{|c|}{ WS03 } & \multicolumn{3}{|c|}{ RS03 } & \multicolumn{3}{|c|}{ RS07 } \\
\hline & $\begin{array}{l}\text { Number of } \\
\text { observations }\end{array}$ & $1 \%$ & $0 \%$ & $\begin{array}{l}\text { Number of } \\
\text { observations }\end{array}$ & $1 \%$ & $0 \%$ & $\begin{array}{l}\text { Number of } \\
\text { observations }\end{array}$ & $1 \%$ & $0 \%$ \\
\hline BLOCK25 & 182 & 87 & 13 & 134 & 84 & 16 & 134 & 82 & 18 \\
\hline BLOCK50 & 182 & 64 & 36 & 134 & 66 & 34 & 134 & 63 & 37 \\
\hline BLOCK_FAMILY & 182 & 46 & 54 & 134 & 50 & 50 & 134 & 35 & 65 \\
\hline BLOCK_GVT & 182 & 12 & 88 & 134 & 8 & 92 & 134 & 5 & 95 \\
\hline AUDIT_DUMMY & 182 & 83 & 17 & 134 & 83 & 17 & 134 & 92 & 8 \\
\hline NOMIN_DUMMY & 182 & 8 & 92 & 134 & 7 & 93 & 134 & 9 & 91 \\
\hline NOMIN_IND_DUMMY & 182 & 5 & 95 & 134 & 5 & 95 & 134 & 7 & 93 \\
\hline COMPENS_DUMMY & 182 & 70 & 30 & 134 & 72 & 28 & 134 & 85 & 15 \\
\hline FAMILY & 182 & 49 & 51 & 134 & 51 & 49 & 134 & 52 & 48 \\
\hline DUALITY & 182 & 35 & 65 & 134 & 34 & 66 & 134 & 28 & 72 \\
\hline PYRAMID & 182 & 74 & 26 & 134 & 78 & 22 & 134 & 79 & 21 \\
\hline INTERLOCK_DUMMY & 182 & 80 & 20 & 134 & 83 & 17 & 134 & 92 & 8 \\
\hline
\end{tabular}


It is worth noting that the number of shareholders owning at least $2 \%$ of capital is relatively low with an average value of 4.37 . Considering the different kinds of owners, in $12 \%$ of cases the biggest shareholder is still the State, while in another $46 \%$ voting rights belong to a single person or to a family.

Considering the board (and internal committees) structure it can be highlighted that on Italian boards there are on average nine (9) members, with a minimum of four (4) and a maximum of twenty-two (22). The proportion of these components that are non executives is 0.62 , but it tends to decrease to 0.35 if the more stringent requirement of independence is taken into consideration.

The CEO/Chairman dual role is also frequent if the value of variable DUALITY, that is $35 \%$, is considered.

The average value of interlocks is not particularly high, but this figure is compensated by the relative frequency with which interlocks interest listed companies (80\%).

From a functional point of view the board held on average 8.28 meetings in the examined year.

Focusing on internal committees, a good result emerges for audit committees that were established in $83 \%$ of the companies in the sample, thus showing a good application of international best practices.

Also in terms of independence level the analysis highlights a good result with $61 \%$ of components being independent and non-executive directors.

In line with these figures are the results for the compensation committee that is present in $70 \%$ of companies.

The situation is different for the nominating committee that is present is only $8 \%$ of cases. Looking at the motivations that are provided to support this choice, usually it is stated that the administrative complexity of the company is not high and there is no need for that committee to be established. Of the same tenor the results concerning independence of the committees that show a $37 \%$ value for the compensation committee; a good result if compared with an extremely low value of the same indicator for the nominating committee: on average only $4.94 \%$ of its members are independent with only $5 \%$ of companies having at least $50 \%$ of independent members.

Before applying regression analysis, we controlled the data distribution looking for possible anomalies.

No significant problems have been found if not for the asymmetry of the number of directors, total assets, and Q-ratio; in all cases the problem was solved with a logarithmic transformation.

Afterwards we conducted a single correlation analysis among non categorical variables, looking for significant relationships.

Observing the correlation matrix (Table 3) it is possible to note how few the significant results are between the regressors and the response variables both for board composition and ownership structure.

For Q-ratio there are three points of correlation that are worth mentioning. The first one is a negative relationship with leverage while the others are the number of audit committee meetings and board dimension which are positively related to performance.

It is worth noting in this first phase that the positive relationship with board dimension is not consistent with the findings of some previous studies that highlighted a negative link (Yermack [16]; Eisenberg and others [22]), corroborating what is stated in Dalton and others [21].

Another interesting result is the positive correlation between Q-ratio and the number of meetings held by the audit committee during the year. Even though it is not possible, to the best of our knowledge, to find supporting evidence in the literature, this relation could be a signal of the appreciation for those audit committees that hold frequent meetings.

We decided to go further with the analysis by drawing a multiple regression model to achieve more evidence on the relationship between governance and performance.

The results are shown in Table 4 (column 1).

The results of multiple regression for Q-ratio showed a negative impact of leverage (although with a very low coefficient) and a positive impact of board dimension. Other four variables seemed to be relevant for performance, although the level of significance is above 0.05 . They are the meetings of the audit committee, the percentage of shares held by management and the presence of the State as the biggest shareholder (all with a positive impact) and the percentage of shares held by the biggest shareholder which was related negatively. As a whole the model presented a R-squared of 0.2881 with a p-value of less than 0.01 .

We conducted some model diagnostics to find out if the Gauss-Markov conditions for the Ordinary Least Squares (OLS) estimators were met.

First of all the collinearity was tested by using the Variance Inflation Factor (VIF). For all variables a value lower than two (2) was obtained, which is acceptable. We tested for self-correlation with the Durbin-Watson test, 
Table 4. Regression models (dependent variable Q-ratio).

\begin{tabular}{|c|c|c|c|c|c|c|c|c|c|}
\hline & \multicolumn{3}{|c|}{ Whole sample (2003) } & \multicolumn{3}{|c|}{ Reduced sample (2003) } & \multicolumn{3}{|c|}{ Reduced sample (2007) } \\
\hline & 1 & 2 & 3 & 4 & 5 & 6 & 7 & 8 & 9 \\
\hline & Linear & Stepwise & Robust & Linear & Stepwise & Robust & Linear & Stepwise & Robust \\
\hline LTDEBT & $\begin{array}{c}0.0000 \\
(0.4297)\end{array}$ & $\mathrm{x}$ & $\mathrm{x}$ & $\begin{array}{c}0.0000 \\
(0.7110)\end{array}$ & $\mathrm{x}$ & $\mathrm{x}$ & $\begin{array}{c}0.0000 \\
(0.9035)\end{array}$ & $\mathrm{x}$ & $\mathrm{x}$ \\
\hline ASSET_LOG & $\begin{array}{r}-0.0334 \\
(0.3562)\end{array}$ & $\mathrm{x}$ & $\mathrm{x}$ & $\begin{array}{l}-0.0265 \\
(0.5850)\end{array}$ & $\begin{array}{l}-0.0528 \\
(0.1237)\end{array}$ & $\begin{array}{l}-0.0564 \\
(0.1402)\end{array}$ & $\begin{array}{c}0.0226 \\
(0.6728)\end{array}$ & $\mathrm{x}$ & $\mathrm{x}$ \\
\hline LEV & $\begin{array}{r}-0.0008 \\
(0.0004)\end{array}$ & $\begin{array}{l}-0.0008 \\
(0.0000)\end{array}$ & $\begin{array}{c}-0.001200 \\
(0.0000)\end{array}$ & $\begin{array}{l}-0.0008 \\
(0.0049)\end{array}$ & $\begin{array}{r}-0.0008 \\
(0.0003)\end{array}$ & $\begin{array}{r}-0.0013 \\
(0.0157)\end{array}$ & $\begin{array}{r}-0.0002 \\
(0.0794)\end{array}$ & $\begin{array}{r}-0.0002 \\
(0.0205)\end{array}$ & $\begin{array}{l}-0.0002 \\
(0.4438)\end{array}$ \\
\hline BOARD_LOG & $\begin{array}{c}0.3957 \\
(0.0169)\end{array}$ & $\begin{array}{c}0.4099 \\
(0.0019)\end{array}$ & $\begin{array}{c}0.420700 \\
0.0037\end{array}$ & $\begin{array}{c}0.3847 \\
(0.0590)\end{array}$ & $\begin{array}{c}0.3931 \\
(0.0146)\end{array}$ & $\begin{array}{c}0.4371 \\
(0.0136)\end{array}$ & $\begin{array}{c}0.4280 \\
(0.0457)\end{array}$ & $\begin{array}{c}0.4224 \\
(0.0058)\end{array}$ & $\begin{array}{r}0.4155 \\
(0.0378)\end{array}$ \\
\hline NED_PERC & $\begin{array}{r}-0.3756 \\
(0.1703)\end{array}$ & $\mathrm{x}$ & $\mathbf{x}$ & $\begin{array}{l}-0.4167 \\
(0.1899)\end{array}$ & $\mathrm{x}$ & $\mathrm{x}$ & $\begin{array}{c}0.0951 \\
(0.7611)\end{array}$ & $\mathrm{x}$ & $\mathrm{x}$ \\
\hline INED_PERC & $\begin{array}{r}-0.0769 \\
(0.8018)\end{array}$ & $\mathrm{x}$ & $\mathrm{x}$ & $\begin{array}{r}-0.0150 \\
(0.9696)\end{array}$ & $\mathrm{x}$ & $\mathrm{x}$ & $\begin{array}{r}-0.9915 \\
(0.0163)\end{array}$ & $\begin{array}{r}-0.4432 \\
(0.1152)\end{array}$ & $\begin{array}{l}-0.0292 \\
(0.9394)\end{array}$ \\
\hline BRDMEET & $\begin{array}{c}0.0038 \\
(0.8226)\end{array}$ & $\mathrm{x}$ & $\mathrm{x}$ & $\begin{array}{l}-0.0031 \\
(0.8877)\end{array}$ & $\mathrm{x}$ & $\mathrm{x}$ & $\begin{array}{c}0.0063 \\
(0.7242)\end{array}$ & $\mathrm{x}$ & $\mathrm{x}$ \\
\hline INTERLOCKS & $\begin{array}{c}0.0150 \\
(0.6125)\end{array}$ & $\mathrm{x}$ & $\mathrm{x}$ & $\begin{array}{l}-0.0003 \\
(0.9935)\end{array}$ & $\mathrm{x}$ & $\mathrm{x}$ & $\begin{array}{l}-0.0123 \\
(0.6968)\end{array}$ & $\mathrm{x}$ & $\mathrm{x}$ \\
\hline AUDIT_IND & $\begin{array}{r}-0.0025 \\
(0.2603)\end{array}$ & $\begin{array}{r}-0.0035 \\
(0.0526)\end{array}$ & $\begin{array}{c}-0.004200 \\
(0.0402)\end{array}$ & $\begin{array}{l}-0.0037 \\
(0.1520)\end{array}$ & $\mathrm{x}$ & $\mathrm{x}$ & $\begin{array}{c}0.0031 \\
(0.2712)\end{array}$ & $\mathrm{x}$ & $\mathrm{x}$ \\
\hline AUDIT_MEET & $\begin{array}{c}0.0413 \\
(0.0914)\end{array}$ & $\begin{array}{c}0.0417 \\
(0.0444)\end{array}$ & $\begin{array}{l}0.041500 \\
(0.0743)\end{array}$ & $\begin{array}{c}0.0490 \\
(0.1075)\end{array}$ & $\begin{array}{c}0.0664 \\
(0.0011)\end{array}$ & $\begin{array}{r}0.0589 \\
(0.0089)\end{array}$ & $\begin{array}{c}0.0080 \\
(0.7469)\end{array}$ & $\mathrm{x}$ & $\mathrm{x}$ \\
\hline NOMIN_IND & $\begin{array}{r}-0.0027 \\
(0.7449)\end{array}$ & $\mathrm{x}$ & & $\begin{array}{r}-0.0048 \\
(0.6579)\end{array}$ & $\mathrm{x}$ & $\mathrm{x}$ & $\begin{array}{l}-0.0306 \\
(0.1030)\end{array}$ & $\mathrm{x}$ & $\mathrm{x}$ \\
\hline COMPENS_IND & $\begin{array}{c}-0.0013 \\
(0.4741)\end{array}$ & $\mathrm{x}$ & & $\begin{array}{l}-0.0002 \\
(0.9204)\end{array}$ & $\mathrm{x}$ & $\mathrm{x}$ & $\begin{array}{c}0.0003 \\
(0.9107)\end{array}$ & $\mathrm{x}$ & $\mathrm{x}$ \\
\hline SIND_CHARGES & $\begin{array}{c}0.0079 \\
(0.7592)\end{array}$ & $\mathrm{x}$ & & $\begin{array}{c}0.0018 \\
(0.9507)\end{array}$ & $\mathrm{x}$ & $\mathrm{x}$ & $\begin{array}{c}0.0014 \\
(0.8044)\end{array}$ & $\mathrm{x}$ & $\mathrm{x}$ \\
\hline SIND_MEET & $\begin{array}{c}-0.0097 \\
(0.5103)\end{array}$ & $\mathrm{x}$ & & $\begin{array}{c}0.0135 \\
(0.4966)\end{array}$ & $\mathrm{x}$ & $\mathrm{x}$ & $\begin{array}{c}0.0065 \\
(0.7155)\end{array}$ & $\mathrm{x}$ & $\mathrm{x}$ \\
\hline SHAREHLDR & $\begin{array}{r}-0.0096 \\
(0.0846)\end{array}$ & $\mathrm{x}$ & $\mathbf{x}$ & $\begin{array}{l}-0.0058 \\
(0.4481)\end{array}$ & $\mathrm{x}$ & $\mathrm{x}$ & $\begin{array}{c}0.0018 \\
(0.6534)\end{array}$ & $\mathrm{x}$ & $\mathrm{x}$ \\
\hline SHARE2_NUM & $\begin{array}{c}0.0008 \\
(0.9674)\end{array}$ & $\mathrm{x}$ & & $\begin{array}{l}-0.0039 \\
(0.8669)\end{array}$ & $\mathrm{x}$ & $\mathrm{x}$ & $\begin{array}{l}-0.0051 \\
(0.7713)\end{array}$ & $\mathrm{x}$ & $\mathrm{x}$ \\
\hline BOWN & $\begin{array}{c}0.0041 \\
(0.0769)\end{array}$ & $\begin{array}{c}0.0032 \\
(0.0467)\end{array}$ & $\begin{array}{c}0.0023 \\
(0.1935)\end{array}$ & $\begin{array}{c}0.0024 \\
(0.4111)\end{array}$ & $\mathrm{x}$ & $\mathrm{x}$ & $\begin{array}{l}-0.0011 \\
(0.6293)\end{array}$ & $\mathrm{x}$ & $\mathrm{x}$ \\
\hline
\end{tabular}




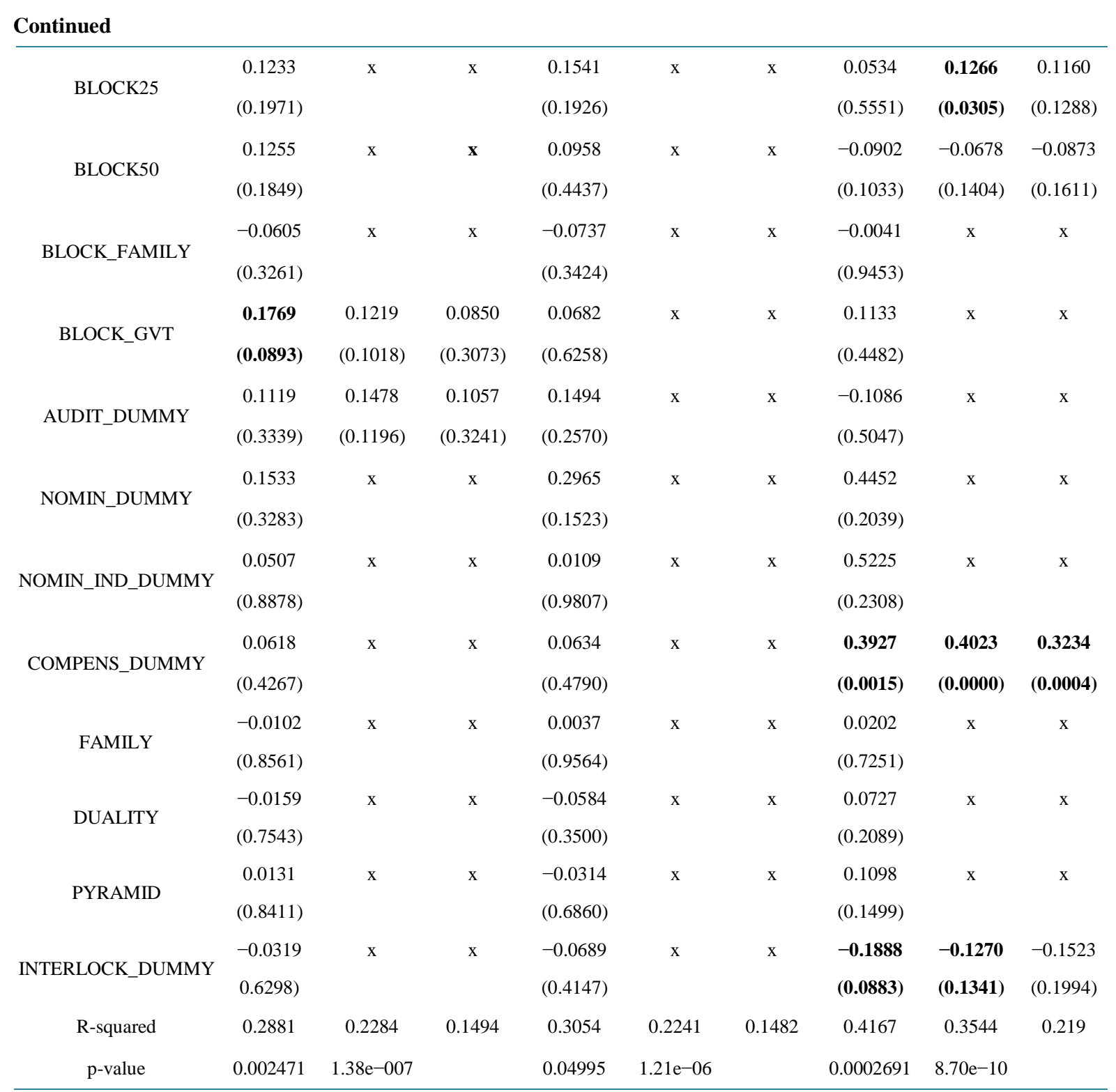

excluding its presence. Analogously encouraging results were obtained testing for normality through the Shapiro-Wilk test.

Some heteroscedasticity problems were evidenced by using the Breusch-Pagan test.

Considering the high number of non significant regressors in the original model it was decided to apply a bidirectional stepwise selection technique to reduce the number of variables and find out the ones with the greatest explanatory power.

The variables SHAREHLDR and BLOCK.GVT lost their significance while audit committee independence rate became significant with a very moderate negative impact. The diagnostic tests for the model concerning Q-ratio were all passed with the exception of Breusch-Pagan.

If heteroscedasticity is present, as the Breusch-Pagan test signalled, the estimators are still correct but it is not possible to make inferences from them because the confidence intervals could be unreliable. To resolve the issue we used a robust MM regression: this allowed them to solve both the heteroscedasticity problem and to get results which were resistant to the effects of possible outliers (Yaffee [59]).

The starting point for robust regression was the model obtained from the stepwise procedure.

Results are shown in column 3. 
Applying robust regression the percentage of shares held by management lost its significance while the other variables kept theirs. Among the positive effects it is possible to find BOARD_LOG and AUDIT_MEET, while LEV03 and AUDIT. IND have a negative impact: for three of the four variables the significance level is below 0.05 . The proportion of variation explained by the model is 0.01494 .

\section{Comparative Analysis 2003-2007}

Since the results of data analysis for the whole sample of companies in 2003 showed few significant impacts of governance variables on performance we decided to investigate if, at least, those effects could keep constant after 4 years by analysing in 2007 the same sample of companies studied for year 2003.

Since in the meantime some companies got delisted, went bankrupt or were simply acquired by other listed companies. We selected a sub sample of companies still listed in 2007.

We got a sample of 134 companies accounting for approximately $71 \%$ of all capitalisation of non financial companies in 2007. We decided to indicate this sample with the name Reduced Sample 2007 (RS07). The omologous sample for 2003 was called Reduced Sample 2003 (RS03).

Comparing those samples some interesting facts emerged (see Table 2 columns II and III).

The ownership structure remained strongly concentrated in 2007 although with a moderate reduction respect to 2003: both the percentage of shareholders holding more than $25 \%$ and $50 \%$ decreased (respectively from $84 \%$ to $82 \%$ and from $66 \%$ to $63 \%$ );

We integrated this comparison with an ANOVA analysis showed in Table 5.

The result of the ANOVA allows to highlight the statistical significance of the average increase in the number of shareholders over the threshold of $2 \%$ of capital: in our samples no significance is showed by the average decrease of the stake held by the biggest shareholder. Notwithstanding this, our results confirm what literature affirms about Italian listed companies ownership structure (Bianco \& Bianchi [58]).

Table 5. Descriptive statistics comparison-ANOVA results.

\begin{tabular}{|c|c|c|c|}
\hline & Average RS03 & Average RS07 & One-way Anova Sig. \\
\hline LTDEBT & 396.59982432 & 873.584.166 & 0.245769881 \\
\hline LTDEBT_LOG & 14.39081369 & 16.18869374 & 0.01921261 \\
\hline ASSET & 2.674.697.139.75 & 2.767.423.772 & 0.94468177 \\
\hline ASSET_LOG & 19.51767849 & 20.05012726 & 0.020865598 \\
\hline LEV & 246.1146269 & 319.7293638 & 0.1202009 \\
\hline BOARD & 9.365671642 & 9.970149254 & 0.123731296 \\
\hline BOARD_LOG & 2.183226768 & 2.249692923 & 0.092373292 \\
\hline NED & 5.843283582 & 6.880597015 & 0.007347983 \\
\hline NED_PERC & 60.83622146 & 67.30219354 & 0.005497154 \\
\hline INED & 3.305970149 & 3.694029851 & 0.140965142 \\
\hline INED_PERC & 35.16289316 & 37.00753263 & 0.380747625 \\
\hline BRDMEET & 7.985074627 & 8.813432836 & 0.05721364 \\
\hline INTERLOCKS & 2.171947761 & 2.501126866 & 0.184128362 \\
\hline AUDIT_IND & 62.15223881 & 72.54783582 & 0.012765871 \\
\hline AUDIT_MEET & 3.067164179 & 4.350746269 & 0.000190851 \\
\hline NOMIN_IND & 4.85 & 5.654925373 & 0.737122956 \\
\hline COMPENS_IND & 37.39626866 & 58.82029851 & 1.18992E-06 \\
\hline SIND_CHARGES & 1.177746269 & 5.892537313 & $7.38219 E-09$ \\
\hline SIND_MEET & 7.462686567 & 8.388059701 & 0.05379249 \\
\hline SHAREHLDR & 49.29121642 & 47.81217164 & 0.507880519 \\
\hline SHARE2_NUM & 4.402985075 & 5.432835821 & 0.017511732 \\
\hline BOWN & 35.07218657 & 37.21070149 & 0.540503785 \\
\hline LOG_TOBIN & -0.062720526 & -0.259702975 & 0.007942543 \\
\hline
\end{tabular}


Considering the different kinds of owners, there is a sharp decrease in the presence of the State $(-37.5 \%$ from $8 \%$ to $5 \%$ ) and of single persons or families ( $-30 \%$ from $50 \%$ to $35 \%$ ) as biggest shareholders.

Observing the board (and internal committees) structure it can be highlighted that, on average, boards increased of 1 member from 2003 to 2007. The increase of the average percentage of non executives in the boards, passing from $60 \%$ to $67 \%$, is encouraging and statistically significant according to ANOVA. This trend is not present when independency is taken into consideration: the average percentage of independent directors within the boards remained approximately stable.

The CEO/Chairman dual role decreased over the years of about $18 \%$ from $34 \%$ to $28 \%$.

Interlocks experienced an increased in more than 10\%: 92\% of the companies in our 2007 sample has at least 1 interlock while they were $83 \%$ in 2003 . This allows saying that, on the one hand interlocks seems to be more common in use and on the other hand that the average number of interlocks per company remained stable.

Focusing on internal committees, a good result emerges for audit committees whose diffusion increased from $83 \%$ to $92 \%$ with a significant increase in independency as well considering that the average number of independent directors increased of more than $16 \%$ (from 62.15 to 72.54 ) .

The results for the compensation committee follow the same trend: they are present in $85 \%$ of companies in 2007 ( $+18 \%$ respect to 2003). Very significant is the increase in the average number of independent directors in compensation committee with more than 58\% in 2007 (they were 37\% in 2003).

Nominating committees has been instituted by $7 \%$ of companies in 2007 while only $5 \%$ used them in 2003, substantially stable their independency level.

As for WS2003, we used linear regression to find out significant effects on performance both for Q-ratio in RS03 and RS07.

For 2003 the complete model (see Table 4 column 4) showed only 2 main effects: one positive (the number of directors in the board) and the other negative (leverage).

The reduction of sample caused all other effects present in the whole sample with a p-value higher than 0.05 to lose their significance.

Applying stepwise regression and robust regression (Table 4 columns 5 and 6 respectively) only the number of meeting of the Audit Committee became significant as it was in the whole sample for 2003.

Examining RS07 the full model confirmed the positive effect of board dimension and the negative relationship of leverage with performance. It is worth noting that in 2007 the effect of leverage, although negative has a much lower coefficient than previous model $(-0.0002$ against the -0.0008 of 2003) and a poorer p-value which is for the first time above 0.05 .

Other effects appeared to be relevant (Table 4 column 7): the percentage of independent directors in the board showed a negative impact of performance as did the presence of interlocks; the institution of a compensation committee had a positive effect on Q-ratio instead. The overall R-squared for the model is 0.4167 with a p-value of 0.0002691 .

Such results did not resist to the stepwise selection procedure and to the robust analysis to which we submitted the full model.

As final result (Table 4 column 9) only two governance variables demonstrated to be relevant for performance in our sample: board dimension and presence of a compensation committee both showed a positive impact on Q-ratio at a significance level lower than 0.01 . For the first time leverage lost its significance; this could be a signal that in 2007 market had not placed a discount to the value of companies in our sample depending on their indebtment. The percentage of variance explained by the model is 0.219 .

\section{Conclusions}

With the present research we wanted to find out how much scope, in the Italian market, there could be for the application of theories and models created in a context that, notwithstanding the increased convergence brought on by globalisation, is still far from the Italian one.

We decided to accomplish that objective by integrating models created abroad with elements that could take into consideration the characteristics of an Italian governance system.

As a whole our intention was to verify whether significant elements of corporate governance could have an influence on performance in a country where family ownership and pyramidal structures are massively present and if this influence could be considered structural.

In Table 6 the work hypotheses and the level of significance evidenced from the analysis were reported. 
Table 6. Dependent variable: Q-ratio.

\begin{tabular}{|c|c|c|c|c|c|c|c|c|c|}
\hline \multirow{3}{*}{ n. } & \multirow{3}{*}{ Hypotheses } & \multirow{3}{*}{ Used variables } & \multirow{3}{*}{$\begin{array}{l}\text { Predicted } \\
\text { sign }\end{array}$} & \multicolumn{2}{|c|}{ Column 1} & \multicolumn{2}{|c|}{ Column 2} & \multicolumn{2}{|c|}{ Column 3} \\
\hline & & & & $\begin{array}{l}\text { Whole } \\
2003( \\
\text { regres }\end{array}$ & $\begin{array}{l}\text { ample } \\
\text { obust } \\
\text { sion) }\end{array}$ & $\begin{array}{r}\text { Redu } \\
2003(r \\
\text { regress }\end{array}$ & $\begin{array}{l}\text { ced } \\
\text { obust } \\
\text { ion) }\end{array}$ & $\begin{array}{r}\text { Redu } \\
2007(\mathrm{r} \\
\text { regres }\end{array}$ & $\begin{array}{l}\text { iced } \\
\text { cobust } \\
\text { sion) }\end{array}$ \\
\hline & & & & Result & Sig. & Result & Sig. & Result & Sig. \\
\hline $\begin{array}{l}\text { HYPOTHESIS } \\
\text { No. } 1\end{array}$ & $\begin{array}{l}\text { A greater proportion of NEDs } \\
\text { corresponds to a } \\
\text { better performance }\end{array}$ & NED_PERC & + & N.S. & & N.S. & & N.S. & \\
\hline $\begin{array}{l}\text { HYPOTHESIS } \\
\text { No. } 2\end{array}$ & $\begin{array}{l}\text { A greater proportion of } \\
\text { INEDs corresponds } \\
\text { to a better performance }\end{array}$ & INED_PERC & + & N.S. & & N.S. & & N.S. & \\
\hline $\begin{array}{l}\text { HYPOTHESIS } \\
\text { No. } 3\end{array}$ & $\begin{array}{l}\text { Board dimension is } \\
\text { positively related to } \\
\text { company performance }\end{array}$ & BOARD_LOG & + & + & 0.001 & + & 0.05 & + & 0.05 \\
\hline $\begin{array}{l}\text { HYPOTHESIS } \\
\text { No. } 4\end{array}$ & $\begin{array}{l}\text { Chairman/CEO duality } \\
\text { is negatively related } \\
\text { to company performance }\end{array}$ & DUALITY & - & N.S. & & N.S. & & N.S. & \\
\hline $\begin{array}{l}\text { HYPOTHESIS } \\
\text { No. } 5 \mathrm{a}\end{array}$ & $\begin{array}{l}\text { The presence of interlocks } \\
\text { is positively related } \\
\text { to company performance }\end{array}$ & INTERLOCK_DUMMY & + & N.S. & & N.S. & & N.S. & \\
\hline $\begin{array}{l}\text { HYPOTHESIS } \\
\text { No. } 5 \mathrm{~b}\end{array}$ & $\begin{array}{l}\text { The number of interlocks } \\
\text { is positively related } \\
\text { to company performance }\end{array}$ & INTERLOCKS & + & N.S. & & N.S. & & N.S. & \\
\hline $\begin{array}{l}\text { HYPOTHESIS } \\
\text { No. } 6\end{array}$ & $\begin{array}{l}\text { The annual number of board } \\
\text { meetings is related to } \\
\text { company performance }\end{array}$ & BOARDMEET & $?$ & N.S. & & N.S. & & N.S. & \\
\hline $\begin{array}{l}\text { HYPOTHESIS } \\
\text { No. 7a }\end{array}$ & $\begin{array}{l}\text { The presence of an audit } \\
\text { committee is positively related } \\
\text { to company performance }\end{array}$ & AUDIT_DUMMY & + & N.S. & & N.S. & & N.S. & \\
\hline $\begin{array}{l}\text { HYPOTHESIS } \\
\text { No. 7b }\end{array}$ & $\begin{array}{l}\text { The degree of independence of } \\
\text { the members of audit committee } \\
\text { is positively related to } \\
\text { company performance }\end{array}$ & AUDIT_IND & + & - & 0.05 & N.S. & & N.S. & \\
\hline $\begin{array}{l}\text { HYPOTHESIS } \\
\text { No. 7c }\end{array}$ & $\begin{array}{l}\text { The annual number of audit } \\
\text { committee meetings is related } \\
\text { to company performance }\end{array}$ & AUDIT_MEET & + & + & 0.1 & + & 0.01 & N.S. & \\
\hline $\begin{array}{l}\text { HYPOTHESIS } \\
\text { No. } 8 \mathrm{a}\end{array}$ & $\begin{array}{l}\text { The presence of a } \\
\text { nominating/compensation } \\
\text { committee is positively related } \\
\text { to company performance }\end{array}$ & $\begin{array}{l}\text { NOMIN_DUMMY/ } \\
\text { COMPENS_DUMMY }\end{array}$ & + & N.S. & & N.S. & & + & 0.001 \\
\hline $\begin{array}{l}\text { HYPOTHESIS } \\
\text { No. } 8 \mathrm{~b}\end{array}$ & $\begin{array}{l}\text { The degree of independence } \\
\text { of the members of } \\
\text { nominating/compensation } \\
\text { committee is positively related } \\
\text { to company performance }\end{array}$ & $\begin{array}{c}\text { NOMIN_IND; } \\
\text { NOMIN_IND_DUMMY }\end{array}$ & + & N.S. & & N.S. & & N.S. & \\
\hline $\begin{array}{l}\text { HYPOTHESIS } \\
\text { No. 9a }\end{array}$ & $\begin{array}{l}\text { The average number of other } \\
\text { board of auditors’ members' } \\
\text { appointments is negatively } \\
\text { related to company performance }\end{array}$ & SIND_CHARGES & - & N.S. & & N.S. & & N.S. & \\
\hline $\begin{array}{l}\text { HYPOTHESIS } \\
\text { No. } 9 \mathrm{~b}\end{array}$ & $\begin{array}{l}\text { The annual number of board of } \\
\text { auditors' meetings is positively } \\
\text { related to company performance }\end{array}$ & SIND_MEET & + & N.S. & & N.S. & & N.S. & \\
\hline $\begin{array}{l}\text { HYPOTHESIS } \\
\text { No. } 10\end{array}$ & $\begin{array}{l}\text { The level of managerial } \\
\text { ownership is related } \\
\text { to company performance }\end{array}$ & BOWN & $+1-$ & N.S. & & N.S. & & N.S. & \\
\hline
\end{tabular}




\begin{tabular}{|c|c|c|c|c|c|c|}
\hline \multicolumn{7}{|l|}{ Continued } \\
\hline $\begin{array}{l}\text { HYPOTHESIS } \\
\text { No. 11a }\end{array}$ & $\begin{array}{l}\text { The share of capital held by } \\
\text { relevant shareholders is } \\
\text { positively related } \\
\text { to company performance }\end{array}$ & SHAREHLDR & + & N.S. & N.S. & N.S. \\
\hline $\begin{array}{l}\text { HYPOTHESIS } \\
\text { No. 11b }\end{array}$ & $\begin{array}{l}\text { The presence of a relevant } \\
\text { shareholder whose } \\
\text { participation goes beyond } \\
\text { certain thresholds is positively } \\
\text { related to company performance }\end{array}$ & $\begin{array}{l}\text { BLOCK_25; } \\
\text { BLOCK_50 }\end{array}$ & + & N.S. & N.S. & N.S. \\
\hline $\begin{array}{l}\text { HYPOTHESIS } \\
\text { No. } 12\end{array}$ & $\begin{array}{l}\text { Family ownership is } \\
\text { positively related to } \\
\text { company performance }\end{array}$ & BLOCK_FAM & + & N.S. & N.S. & N.S. \\
\hline $\begin{array}{l}\text { HYPOTHESIS } \\
\text { No. } 13\end{array}$ & $\begin{array}{l}\text { State ownership is } \\
\text { negatively related to } \\
\text { company performance }\end{array}$ & BLOCK_GVT & - & N.S. & N.S. & N.S. \\
\hline $\begin{array}{l}\text { HYPOTHESIS } \\
\text { No. } 14\end{array}$ & $\begin{array}{l}\text { Pyramidal control mechanisms } \\
\text { are negatively related to } \\
\text { company performance }\end{array}$ & PYRAMID & - & N.S. & N.S. & N.S. \\
\hline
\end{tabular}

Out of the 14 hypotheses formulated mainly on the basis of theory, only 3 were significant if looking at WS03 (column 1) but the figures reduced to two by looking at RS03 and RS07 (columns 2 and 3).

The only significant effect which was found to be significant in any case is board dimension with a positive impact on performance (Hypothesis No. 3): it is a point which can corroborate both agency theory, that attributes a monitoring role to directors, and a resource base view which considers management as a source of high level skills and knowledge. The emphasis on dimension, anyway, does not allow inferring anything about the characteristics of board: dependence or independence of board members is a quality that has no impact to performance according to our results.

Apart from board dimension in 2003 samples, it can be stated that audit committee had an influence on performance. From our data the market seems to attribute a premium to those companies with an active audit committee: this could be explained by the consideration that greater assiduity could be perceived as a more continuous monitoring activity. What is also interesting is that the market seems to appreciate whether the audit committee is composed prevalently of insiders (see Hypotheses 7b and 7c). It appears meaningful to affirm that this could happen because insiders were thought to have deeper knowledge of the entity's operations. Unfortunately this same result is not confirmed in 2007 sample showing the weakness of drawing such conclusion.

Also interesting is the fact that in 2007 the companies that decided to create a compensation committee registrered a better performance. Under an agency theory perspective it can be said that the presence of this committee allow the companies to better match market results with executives compensation plans thus reducing opportunistic behaviour. Unfortunately compensation committee had no impact on performance in 2003 thus showing again the lack of structural impact of this governance variable on performance as we said for audit committee above.

Summarizing all our previous considerations we can say that in our data the relationship between governance structure as represented by the selected variables and company performance (Q-ratio) is weak and does not allow to inferring that a particular governance or ownership structure can be relevant to improve the value of a company overtime.

This seems to confirm what other authors studying Italian market (Belcredi \& Rigamonti [1]) concluded about the ambiguous relationship between ownership and corporate governance structure and firm valuation. This ambiguity risk improves if this relationship is investigated overtime.

\section{References}

[1] Belcredi, M. and Rigamonti, S. (2008) Ownership and Board Structure in Italy (1978-2003). Proceedings of the EFMA Annual Meeting, Athens, 25-28 June 2008, 1-36.

[2] Abdel-khalik, A.R. (2002) Reforming Corporate Governance Post Enron: Shareholders' Board of Trustees and the Auditor. Journal of Accounting and Public Policy, 21, 97-103. http://dx.doi.org/10.1016/S0278-4254(02)00040-6 
[3] Revsine, L. (2002) Enron: Sad but Inevitable. Journal of Accounting and Public Policy, 21, 137-145. http://dx.doi.org/10.1016/S0278-4254(02)00044-3

[4] Blair, M.M. (2002) Post Enron Reflections on Comparative Corporate Governance. Business, Economics and Regulatory Law_Working Paper No. 316663, Georgetown University Law Centre, Washington DC.

[5] Palepu, K. and Healy, P.M. (2003) The Fall of Enron. Journal of Economic Perspectives, 17, 3-26. http://dx.doi.org/10.2139/ssrn.417840

[6] Berle, A. and Means, G. (1932) The Modern Corporation and Private Property. Commerce Clearing House, New York.

[7] Shleifer, A. and Vishny, R. (1997) A Survey of Corporate Governance. Journal of Finance, 52, 737-783. http://dx.doi.org/10.1111/j.1540-6261.1997.tb04820.x

[8] Jensen, M.C. and Meckling, W.H. (1976) Theory of the Firm: Managerial Behaviour, Agency Costs and Ownership Structure. Journal of Financial Economics, 3, 305-360. http://dx.doi.org/10.1016/0304-405X(76)90026-X

[9] Fama, E.F. and Jensen, M.C. (1983) Separation of Ownership and Control. Journal of Law and Economics, 26, 301325. http://dx.doi.org/10.1086/467037

[10] Keasey, K., Thompson, S. and Wright, M. (1997) Corporate Governance: Economic and Financial Issues. Oxford University Press, Norfolk.

[11] Fama, E.F. (1980) Agency Problems and the Theory of the Firm. Journal of Political Economy, 88, 288-307. http://dx.doi.org/10.1086/260866

[12] Hermalin, B.E. and Weisbech, M.S. (1991) The Effects of Board Composition and Direct Incentives on Firm Performance. Papers 91-02, Business-Financial Research and Policy Studies, Rochester.

[13] Bhagat, S. and Black, B. (2001) The Non-Correlation between Board Independence and Long Term Firm Performance. Journal of Corporation Law, 27, 231-274.

[14] Dulecwicz, V. and Herbert, P. (2004) Does the Composition and Practice of Boards of Directors Bear Any Relationship to the Performance of their Companies? Corporate Governance: An International Review, 12, 263-280. http://dx.doi.org/10.1111/j.1467-8683.2004.00368.x

[15] Pfeffer, J. (1972) Size and Composition of Corporate Boards of Directors: The Organization and Its Environment. Administrative Science Quarterly, 17, 218-228. http://dx.doi.org/10.2307/2393956

[16] Yermack, D. (1996) High Market Valuation of Companies with a Small Board of Directors. Journal of Financial Economics, 40, 185-211. http://dx.doi.org/10.1016/0304-405X(95)00844-5

[17] Muth, M. and Donaldson, L. (1998) Stewardship Theory and Board Structure: A Contingency Approach. Corporate Governance: An International Review, 6, 2-28. http://dx.doi.org/10.1111/1467-8683.00076

[18] Agrawal, A. and Knoeber, C.R. (1999) Outside Directors, Politics, and Firm Performance. http://ssrn.com/abstract $=85310$

[19] Dehaene, A., De Vuyst, V. and Ooghe, H. (2001) Corporate Performance and Board Structure in Belgian Companies. Long Range Planning, 34, 383-398. http://dx.doi.org/10.1016/S0024-6301(01)00045-0

[20] Kiel, G.C. and Nicholson, G.J. (2003) Board Composition and Corporate Performance: How the Australian Experience Informs Contrasting Theories of Corporate Governance. Corporate Governance: An International Review, 11, 189-205. http://dx.doi.org/10.1111/1467-8683.00318

[21] Dalton, D.R., Daily, C.M., Johnson, J.L. and Ellstrand, A.E. (1999) Number of Directors and Financial Performance: A Meta-Analysis. The Academy of Management Journal, 42, 674-686. http://dx.doi.org/10.2307/256988

[22] Eisenberg, T., Sundgren, S. and Wells, M.T. (1998) Larger Board Size and Decreasing Firm Value in Small Firms. Journal of Financial Economics, 48, 35-54. http://dx.doi.org/10.1016/S0304-405X(98)00003-8

[23] Lipton, L. and Lorsch, J. (1992) A Modest Proposal for Improved Corporate Governance. The Business Lawyer, 48, 59-77.

[24] Jensen, M.C. (1993) The Modern Industrial Revolution, Exit, and the Failure of Internal Control Systems. The Journal of Finance, 48, 831-880. http://dx.doi.org/10.2307/2329018

[25] Boyd, B.K. (1995) CEO Duality and Firm Performance: A Contingency Model. Strategic Management Journal, 16, 301-312. http://dx.doi.org/10.1002/smj.4250160404

[26] Dalton, D.R., Daily, C.M., Ellstrand, A.E. and Johnson, J.L. (1998) Meta-Analytic Reviews of Board Composition, Leadership Structure, and Financial Performance. Strategic Management Journal, 19, 269-290. http://dx.doi.org/10.1002/(SICI)1097-0266(199803)19:3<269::AID-SMJ950>3.0.CO;2-K

[27] Vafeas, N. and Theodorou, E. (1998) The Relationship between Board Structure and Firm Performance in the UK. The British Accounting Review, 30, 383-407. http://dx.doi.org/10.1006/bare.1998.0075

[28] Dowen, R.J. (1995) Board Director Quality and Firm Performance. International Journal of the Economics of Business, 


\section{2, 123-132. http://dx.doi.org/10.1080/758521100}

[29] Klein, A. (1998) Firm Performance and Board Committee Structure. Journal of Law and Economics, 16, 275-303. http://dx.doi.org/10.1086/467391

[30] Wild, J.J. (1994) Managerial Accountability to Shareholders: Audit Committees and the Explanatory Power of Earning for Returns. British Accounting Review, 26, 353-374. http://dx.doi.org/10.1006/bare.1994.1024

[31] Brown, L.D. and Caylor, M.L. (2004) Corporate Governance and Firm Performance. http://ssrn.com/abstract=586423

[32] Morck, R., Shleifer, A. and Vishny, R.W. (1988) Management Ownership and Market Valuation. Journal of Financial Economics, 20, 293-315. http://dx.doi.org/10.1016/0304-405X(88)90048-7

[33] McConnell, J.J. and Servaes, H. (1990) Additional Evidence on Equity Ownership and Corporate Value. Journal of Financial Economics, 27, 595-612. http://dx.doi.org/10.1016/0304-405X(90)90069-C

[34] Holderness, C., Kroszner, R. and Sheehan, D. (1999) Were the Good Old Days That Good? Changes in Managerial Stock Ownership since the Great Depression. Journal of Finance, 54, 435-469. http://dx.doi.org/10.1111/0022-1082.00114

[35] Short, H. and Keasey, K. (1999) Managerial Ownership and the Performance of Firms: Evidence from the UK. Journal of Corporate Finance, 5, 79-101. http://dx.doi.org/10.1016/S0929-1199(98)00016-9

[36] Lins, K. (2002) Equity Ownership and Firm Value in Emerging Markets. Journal of Financial and Quantitative Analysis, 38, 159-184. http://ssrn.com/abstract=331320 http://dx.doi.org/10.2307/4126768

[37] La Porta, R., Lopez-de-Sinales, F., Shleifer, A. and Vishny, R. (2002) Investor Protection and Corporate Valuation. Journal of Finance, 57, 1147-1170. http://dx.doi.org/10.1111/1540-6261.00457

[38] Demsetz, H. and Villalonga, B.(2001) Ownership Structure and Corporate Performance. Journal of Corporate Finance, 7, 209-233. http://dx.doi.org/10.1016/S0929-1199(01)00020-7

[39] Volpin, P. (2002) Governance with Poor Investor Protection: Evidence from Top Executive Turnover in Italy. Journal of Financial Economics, 64, 61-90. http://dx.doi.org/10.1016/S0304-405X(02)00071-5

[40] Denis, D.K. and McConnell, J.J. (2003) International Corporate Governance. Finance Working Paper No. 5/03, ECGI.

[41] Bianco, M. and Casavola, P. (1999) Italian Corporate Governance: Effects on Financial Structure and Firm Performance. European Economic Review, 43, 1057-1069. http://dx.doi.org/10.1016/S0014-2921(98)00114-7

[42] Bianchi, M., Bianco, M. and Enriques, L. (2002) Pyramidal Groups and the Separation between Ownership and Control in Italy. In: Barca, F. and Becht, M., Eds., The Control of Corporate Europe, Oxford University Press, Oxford, 154-188. http://dx.doi.org/10.1093/0199257531.003.0006

[43] La Porta, R., Lopez-de-Sinales, F. and Shleifer, A. (1998) Corporate Ownership around the World. NBER Working Paper No. W6625. http://ssrn.com/abstract=226343

[44] Faccio, M. and Lang, L.H.P. (2002) The Ultimate Ownership of Western European Corporations. Journal of Financial Economics, 65, 365-395. http://dx.doi.org/10.1016/S0304-405X(02)00146-0

[45] Holderness, C. and Sheehan, D. (1988) The Role of Majority Shareholders in Publicly Held Corporations. Journal of Financial Economics, 20, 317-346. http://dx.doi.org/10.1016/0304-405X(88)90049-9

[46] Anderson, R. and Reeb, D.M. (2003) Founding Family Ownership and Firm Performance: Evidence from the S\&P 500. Journal of Finance, 58, 1301-1329. http://dx.doi.org/10.1111/1540-6261.00567

[47] Villalonga, B. and Amit, R.H. (2004) How Do Family Ownership, Control, and Management Affect Firm Value? AFA 2005 Philadelphia Meetings; EFA 2004 Maastricht Meetings Paper No. 3620. http://ssrn.com/abstract=556032

[48] Ben-hamar, W. and André, P. (2005) Separation of Ownership from Control and Acquiring Firm Performance: The Case of Family Ownership in Canada. http://ssrn.com/abstract=676352

[49] Górriz, C.G. and Fumás, V.S. (2005) Family Ownership and Performance: The Net Effect of Productive Efficiency and Growth Constraints. Finance Working Paper No. 66/05, ECGI.

[50] Barontini, R. and Caprio, L. (2005) The Effect of Family Control on Firm Value and Performance: Evidence from Continental Europe. Finance Working Paper No. 88/05, ECGI.

[51] Kocenda, E. and Svejnar, J. (2002) The Effects of Ownership Forms and Concentration on Firm Performance after Large-Scale Privatization. William Davidson Institute Working Papers Series, No. 471a.

[52] Grünfeld, L.A., Benito, G.R.G. and Goldeng, E. (2004) The Inferior Performance of State Owned Enterprises: Is It Due to Ownership or Market Structure? NUPI Working Paper No. 663. http://ssrn.com/abstract=741787

[53] Tian, L. and Estrin, S. (2005) Retained State Shareholding in Chinese PLCs: Does Government Ownership Reduce Corporate Value? IZA Discussion Paper Series No. 1493. 
[54] Lemmon, M. and Lins, K. (2001) Ownership Structure, Corporate Governance, and Firm Value: Evidence from the East Asian Financial Crises. William Davidson Institute Working Papers Series, No. 393.

[55] Melis, A. (1998) Corporate Governance in Europe. An Empirical Analysis of the Italian Case among Non Financial Listed Companies. Working Paper. http://ssrn.com/abstract=168728

[56] Tobin, J. (1969) A General Equilibrium Approach to Monetary Theory. Journal of Money, Credit and Banking, 1, 1529. http://dx.doi.org/10.2307/1991374

[57] Aganin, A. and Volpin, P. (2003) History of Corporate Ownership in Italy. Finance Working Paper No. 17/03, ECGI.

[58] Bianchi, M. and Bianco, M. (2006) Italian Corporate Governance in the Last 15 Years: From Pyramids to Coalitions. Finance Working Papers No. 144/2006, ECGI. http://ssrn.com/abstract_id=952147

[59] Yaffee, R. (2002) Robust Regression Analysis: Some popular Statistical Package Options. ITS, New York University, New York. 